\title{
Migration of natural hydrogen from deep-seated sources in the São Francisco Basin, Brazil
}

\author{
Frédéric-Victor Donzé 1,* Laurent Truche 1, Parisa Shekari Namin ${ }^{1}$, Nicolas Lefeuvre and Elena \\ F. Bazarkina ${ }^{2}$ \\ 1 Univ. Grenoble Alpes, Univ. Savoie Mont Blanc, CNRS, IRD, IFSTTAR, ISTerre, 38000 Grenoble, France \\ 2 Univ. Grenoble Alpes, Institut Néel, UPR 2940 CNRS, 38000 Grenoble, France \\ * Correspondence: frederic.donze@univ-grenoble-alpes.fr;
}

\begin{abstract}
Hydrogen gas is seeping from the sedimentary basin of São Franciso, Brazil. The seepages of $\mathrm{H}_{2}$ are accompanied by helium whose isotopes reveal a strong crustal signature. Geophy sical data indicates that this intra-cratonic basin is characterized by i) a relatively high geothermal gradient, ii) deep faults delineating a horst and graben structure and affecting the entire sedimentary sequence, iii) an archean to paleoproterozoïc basements enriched in radiogenic elements and displaying mafic and ultramafic units, and iv) a possible karstic reservoir located $400 \mathrm{~m}$ below the surface. The high geothermal gradient could be due to a thin lithosphere enriched in radiogenic elements, which can also contribute to a massive radiolysis process of water at depth, releasing a significant amount of $\mathrm{H}_{2}$. Alternatively, ultramafic rocks that may have generated $\mathrm{H}_{2}$ during their serpentinization are also documented in the basement. The seismic profiles show that the faults seen at the surface are deeply rooted in the basement, and can drain deep fluids to shallow depths in a short time scale. The carbonate reservoirs within the Bambuí group which forms the main part of the sedimentary layers are crossed by the fault system and represent good candidates for temporary $\mathrm{H}_{2}$ accumulation zones. The formation by chemical dissolution of sinkholes located at $400 \mathrm{~m}$ depth might explain the presence of sub-circular depressions seen at the surface. These sinkholes might control the migration of gas from temporary storage reservoirs in the upper layer of the Bambuí formation to the surface. The fluxes of $\mathrm{H}_{2}$ escaping out of these structures, which have been recently documented, are discussed in light of the newly developed $\mathrm{H}_{2}$ production model in the Precambrian continental crust.
\end{abstract}

Keywords: Native hydrogen; $\mathrm{H}_{2}$ exploration; Gas seeps; $\mathrm{H}_{2}$ venting; Radiolysis; Serpentinization; Draining Faults, Intra-Cratonic Basin.

\section{Introduction}

The natural production of molecular hydrogen (hereafter hydrogen or $\mathrm{H}_{2}$ ) has drawn increasing scientific attention due to the central role this molecule plays in fueling the deep subsurface biosphere or promoting the abiotic synthesis of organic molecules (Truche et al, 2020 [1]). Natural $\mathrm{H}_{2}$ sources may also represent a new attractive primary carbon free energy resource (Smith, 2002 [2]; Smith et al., 2005 [3]; Truche and Bazarkina, 2019 [4]; Gaucher, 2020 [5]). This latter industrial perspective has motivated recent $\mathrm{H}_{2}$ exploration studies in ophiolite, peralkaline, Precambrian shields and intracratonic geological settings (see review by Zgonnik, 2020 [6]).

Natural hydrogen (also known as native hydrogen) sources have been identified for several decades in seafloor hydrothermal vents, and hyperalkaline springs in ophiolite massifs. Serpentinization of ultramafic rocks is the water-rock interaction process responsible for $\mathrm{H}_{2}$ generation in these contexts (Neal and Stranger, 1983 [7]; Coveney et al., 1987 [8]; Abrajano et al., 1990 [9]; Charlou et al., 1996 [10]; Seewald et al., 2003 [11]). How ever, the recent discoveries of intracratonic $\mathrm{H}_{2}$ seepages and accumulations with no obvious link to an ultramafic formation challenge our current understanding of $\mathrm{H}_{2}$ production and fate in the crust (Larin et al., 2015 [12];Zgonnik et 
al., 2015 [13], Prinzhofer et al., 2018 [14]). To date, there is no in-depth understanding of the hydrogen system from source to seep in these latter geological set tings. When not fortuitous, as in the Taoudeni Basin in Mali (Prinzhofer et al., 2018 [14]), the discoveries of new $\mathrm{H}_{2}$ seepages were made thanks to the satellite detection of sub-circular soil depressions displaying vegetation anomalies, e.g. Borisoglebsk in Russia (Larin et al., 2015 [12]), Carolina Bay in the US (Zgonnik et al., 2015 [13]). These surface features are the only evidences used to detect these $\mathrm{H}_{2}$ seepages. This limited understanding of the $\mathrm{H}_{2}$ systems, and this lack of robust pathfinders prevents the development of a methodic exploration strategy or resource assessment in these environments.

The São Francisco Basin belongs to this short list of intra-cratonic basins where $\mathrm{H}_{2}$ seepages have been discovered. There, hydrogen gas vents from slight topographic depressions that are circular and barren of vegetation and in one of them, the recorded $\mathrm{H}_{2}$ concentrations range from $50 \%$ to $80 \%$ (Prinzhofer et al., 2019 [15]; Cathles \& Prinzhofer, 2020 [16]). Also in the area of the São Francisco Basin, Flude et al. (2019 [17]), recorded up to $20 \%$ of $\mathrm{H}_{2}$, mostly accompanied with $\mathrm{N}_{2}$ and several percents of $\mathrm{CH}_{4}$, in the gas mixture from the head of exploration wells and natural gas seeps.

The São Francisco basin provides one of the first $\mathrm{H}_{2}$ case study where geological information can be collected with a sufficient level of details to provide the primary elemental bricks that may compose the $\mathrm{H}_{2}$ system in intra-cratonic basins. Here, we review the different layers of information that compose a supposed $\mathrm{H}_{2}$ system in this basin and lay the foundation of an $\mathrm{H}_{2}$ exploration guide.

\section{The São Francisco basin}

Located in the Brazilian states of Minas Gerais and Bahia, the São Francisco Craton presents rocks dating back from the Paleoarchean to the Cenozoic and several Precambrian sedimentary successions (Heilbron, 2017 [18]) (Figure 1). The basement is mostly composed of Archean TTG (Tonalite-Trondhjemite-Granodiorite) rocks, granitoids and greenstones belts (Anhaeusser, 2014 [21]) together with Paleoproterozoic plutons and supra-crustal successions. This polycyclic substratum assembled during late Neoarchean times under high-grade metamorphic conditions, is intruded by late tectonic K-rich granites, mafic-ultramafic units, and mafic dikes (Teixeira et al., 2017 [22]). The Southern part of the São Francisco Craton consists of several gneiss complexes and greenstone belts from the Mineiro orogeny.

The sedimentary cover is made up of units younger than $1.8 \mathrm{Ga}$ : the São Francisco basin (Southern part), the Paramirin Aulacogen (Northern part) and the Recôncavo-Tucano-Jatoba rift (Northeastern part) (Heilbron et al., 2017 [18]). Besides these Proterozoic sedimentary successions, theSão Francisco basin also contains Phanerozoic units (Permo-Carboniferous and Cretaceous rocks).

Along the southern edge of the São Franciso basin, the Bambuí Group fills a series of buried grabens. The Bambuí strata exposed along the area of interest in this study are generally flat lying and cover more than $300,000 \mathrm{~km}^{2}$. The entire basin is covered by a 450 to $1800 \mathrm{~m}$-thick Neoproterozoic to Cambrian sedimentary successions, which are unconformably overlying the ArcheanPaleoproterozoic basement (Delpomdor et al., 2020 [23]) (Figure 1b).

\section{3. $H_{2}$ seepages in the Bambuí Group in the Southern part of the São Francisco Basin}

To constrain the magnitude of the $\mathrm{H}_{2}$ emission, a permanent monitoring station has been installed in a depression located $16 \mathrm{~km}$ North-North East of Santa Fé de Minas in the State of Mina Gerais (Prinzhofer et al., 2019 [15]) (Figure 2). The recorded emission rates range from $7000 \mathrm{~m}^{3}$ to $178,000 \mathrm{~m}^{3}$ of $\mathrm{H}_{2}$ per day with $\mathrm{H}_{2}$ concentrations in the venting gas on the order of $1000 \mathrm{ppm}$ (Cathles \& Prinzhofer, $2020[16])$.

In the same area, various geophysical data acquisitions have been previously obtained from surface monitoring or exploration wells. Seismic and magnetotelluric sections show the distribution of the main stratigraphic units across the São Francisco basin (e.g. Romeiro-Silva \& Zalán, 2005 [24]; Reis \& Alkmim, 2015 [25]; Solon et al., 2015 [20]) (Figure 1b). 

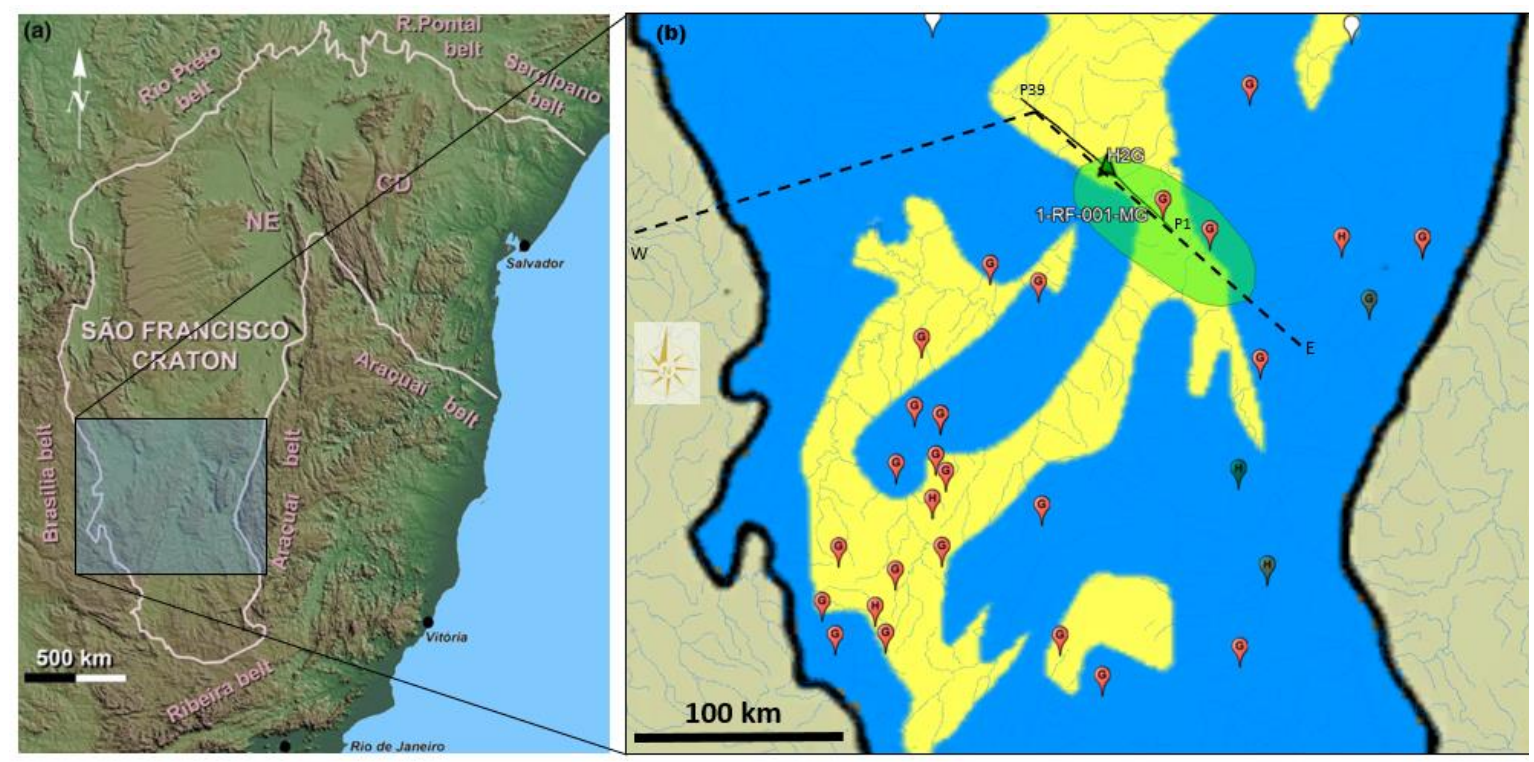

Figure 1. (a) Digital elevation model of southeastern Brazil, showing the topography associated with the São Francisco Craton outlined by the pink line (From Heilbron et al., 2017 [18]). (b) Simplified geological map (CPRM Serviço Geológico do Brasil) of the Southern part of the São Francisco Basin, outline d by the black line, with the Bambuí group in Yellow, the Phanerozoiccover in blue. Gas seepages $\left(\mathrm{H}_{2}, \mathrm{~N}_{2}, \mathrm{He}\right.$, Hydrocarbons) have been observed during field investigations inside the green ellipse (Curto et al., 2012 [19]) and the triangle H2G corre sponds to the gas seepage presented in Figure 2 (Prinzhofer et al.; 2019 [15]). The red markers, including the 1-RD-001-MG well, indicate locations of the exploration wells. The E-W (East-West) black dash line corre sponds to the seismic sections presented in Figure 3. The solid black line linking the P1 and P39 white markers corresponds to the Magnetotelluric stations for the MT1 line set up in São Francisco Basin by Solon et al. (2015 [20]).

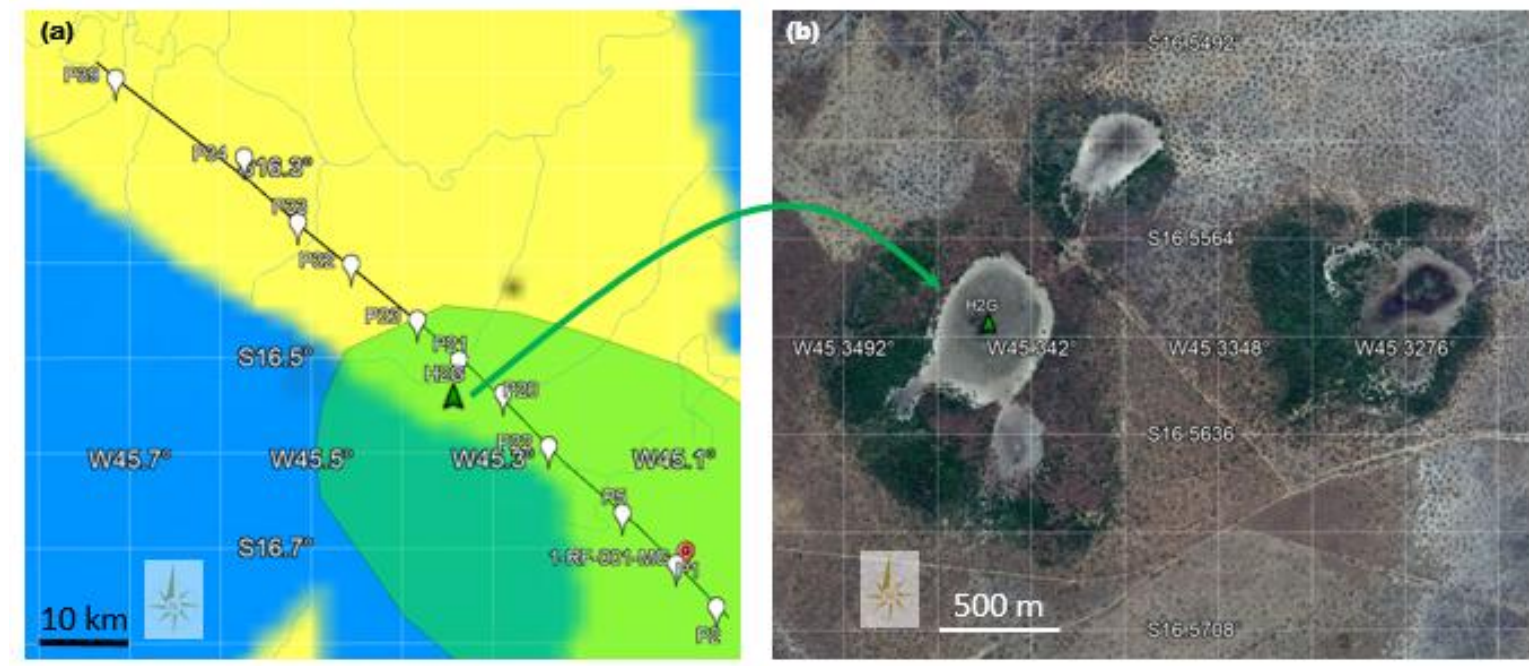

Figure 2. (a) Magne totelluric stations for the MT1 line set up in São Francisco Basin by Solon et al. (2015 [20]) with the location of well 1-RF-001-MG, from Figure 1b. (b) $\mathrm{H}_{2}$ seepages (H2G) observed in circular de pression zones (16³3.605'South; $45^{\circ} 20.620^{\prime}$ West) (Prinzhofer et al., 2019 [15]).

The Bambuí group includes seven stratigraphic units. Logs from the 1-RF-001-MG well located near station P1 on line MT1 (Figure 2a), provide quantitative information regarding the thickness of each geological layer to a depth of $1848 \mathrm{~m}$ with the sequences listed in Table 1 . The depositional age 
of the Bambuí Group, especially its lower part, remains controversial, e.g. the estimated date varies from $560 \mathrm{Ma}$ to $762 \mathrm{Ma}$ for the low ermost part of the Sete Lagoas (Delpomdor et al., 2020 [23]).

Table 1. Simplified interpretation of the well log data from the Petrobras' well 1-RF-1-MG (From Solon et al., 2015 [20]).

\begin{tabular}{|c|c|c|}
\hline Depth & Composition & Lithology \\
\hline [surface to $\sim 30 \mathrm{~m}$ ] & $\begin{array}{ll}\text { - } & \text { Siltstones and } \\
\text { sandstone } \\
\text { - Mainly composed of } \\
\text { sandstone, siltstone, } \\
\text { mudstone and shale }\end{array}$ & $\begin{array}{l}\text { Serra de Saudade } \\
\text { Formation }\end{array}$ \\
\hline $\begin{array}{l}{[\sim 320 \mathrm{~m} \text { to } \sim 480 \mathrm{~m}]} \\
{[\sim 380 \mathrm{~m} \text { to } \sim 680 \mathrm{~m}]}\end{array}$ & $\begin{array}{ll}\text { - } & \text { Limestone } \\
\text { - } & \text { Intercalations of } \\
& \text { limestone and shale }\end{array}$ & $\begin{array}{l}\text { Lagoa do Jacaré } \\
\text { Formation }\end{array}$ \\
\hline $\begin{array}{l}{[\sim 680 \mathrm{~m} \text { to } \sim 980 \mathrm{~m}]} \\
{[\sim 980 \mathrm{~m} \text { to } \sim 1200 \mathrm{~m}]}\end{array}$ & $\begin{array}{l}\text { - Mainly composed of } \\
\text { siltstone } \\
\text { - Mainly consisting of } \\
\text { limestone and } \\
\text { dolomite }\end{array}$ & $\begin{array}{l}\text { Serra de Santa } \\
\text { Helena Formation }\end{array}$ \\
\hline$[\sim 1200 \mathrm{~m}$ to $\sim 1240 \mathrm{~m}]$ & $\begin{array}{l}\text { - Mainly consisting of } \\
\text { limestone and } \\
\text { dolomite }\end{array}$ & $\begin{array}{l}\text { Sete Lagoas } \\
\text { Formation }\end{array}$ \\
\hline below 1640 m & $\begin{array}{l}\text { Composed of } \\
\text { intercalations of } \\
\text { shales and limestone, } \\
\text { conglomerates and } \\
\text { diamictite } \\
\text { Composed of shale, } \\
\text { limestone and } \\
\text { conglomerate }\end{array}$ & Jequitaí Formation \\
\hline
\end{tabular}

\section{A possible deep origin for $\mathrm{H}_{2}$}

In addition to $\mathrm{H}_{2}$ venting at location $\mathrm{H}_{2} \mathrm{G}$ (Figure $2 \mathrm{~b}$ ), He concentrations (5 ppm above atmospheric reference value) measured by Prinzhofer et al. (2019 [15]) at a depth of $1 \mathrm{~m}$, suggest a possible gas migration from deep horizons, where He is generated. Other analyses of gas sampled at the surface, from the head of exploration wells drilled in the São Francisco basin confirmed that, besides high concentrations of $\mathrm{H}_{2}$ (up to $20 \%$ ), $\mathrm{He}(>1 \%)$ is also present, in association with methanedominated hydrocarbons and $\mathrm{N}_{2}$ (Flude et al., 2019 [17]). Stable isotope data also suggest an abiotic origin for the methane, while He isotopes reveal a strong crustal signature $\left({ }^{3} \mathrm{He} /{ }^{4} \mathrm{He}<0.02 \mathrm{R} / \mathrm{Ra}\right)$ (Flude et al., 2019 [17]). Thenucleogenic ${ }^{3} \mathrm{He}$ from the decay of ${ }^{6} \mathrm{Li}$ could account for the ${ }^{3} \mathrm{He} /{ }^{4} \mathrm{He}$ ratios found in the head of exploration wells drilled in the São Francisco basin, i.e. close to R/Ra $=0.01$ for an average granitic crust. Moreover, Neon isotope data also suggest the presence of an Archaean crustal component in the gases, indicating that a component of the gas has likely originated from the underlying crystalline basement, or within Archaean-derived sedimentary rocks (Flude et al., 2019 [17]).

The natural production of the continental $\mathrm{H}_{2}$ can be of various origins (Guélard et al., 2017 [26]). Studies in deep mines from the Witwatersrand basin (South Africa) and the Timmins basin (Ontario, Canada) have suggested a link between dissolved $\mathrm{H}_{2}$ and the radiolytic dissociation of water (Lin et al., 2005a [27]). In addition to radiolysis, hydration of ultramafic rocks coupled to $\mathrm{H}_{2} \mathrm{O}$ reduction could also be responsible for $\mathrm{H}_{2}$ generation in Precambrian shields (Goebel et al., 1984 [28]; Sherw ood 
Lollar et al., 2014 [29]). For example, the serpentinization of the gabbroic basement has been proposed as the process responsible for $\mathrm{H}_{2}$ production in Kansas (Coveney et al., 1987 [8]).

Radiolysis and serpentinization both require specific environments, which can be identified from geophysical and mineralogical investigations. Regarding the São Francisco basin, we detail these two possible processes of $\mathrm{H}_{2}$ formation in the following subsections.

\section{Production of $\mathrm{H}_{2}$ by water radiolysis}

Distinct Archean gneissic-granitic complexes characterize the Southern part of the São Francisco Craton basement. They constitute a medium- to high-grade metamorphic terrain that crops out from the Quadrilátero Ferrífero tow ards the west, and mainly comprises TTG rocks, migmatites and Krich granitic plutons (Teixeira et al., 2017 [22]). These rocks record deformational and metamorphic Archean episodes (from 2.55 Ga to over 3.3 Ga). It is known that the crystalline basement, rich in radiogenic elements and particularly this type of old basement Precambrian rocks, represent potentially fertile deep-seated sources of $\mathrm{H}_{2}$ (Parnell et al., 2017 [30]; Sherw ood Lollar et al., 2014 [31]). Indeed, molecular hydrogen production from water radiolysis requires the presence of radiogenic elements such as $\mathrm{U}$, Th or $\mathrm{K}$, which splits the water molecules by ionizing radiation to produce molecules of $\mathrm{H}_{2}$. For the São Francisco Craton, the measured concentrations of uranium (U), thorium (Th) and potassium (K) are presented in Table 2. The Bambuí Group exhibits intermediate-to-high K and Th contents, while U-levels are around 2.5 ppm (Reis et al., 2012 [34]).

Table 2. Measured concentrations of Uranium, Thorium and Potassium.

\begin{tabular}{llll}
\hline Radioelement & $\begin{array}{l}\text { Archean granulitic rocks } \\
\text { of the Jequie complex }\end{array}$ & $\begin{array}{l}\text { Brauna Kimberlite } \\
\text { present in the } \\
\text { Archean basement }^{2}\end{array}$ & Bambuí Group \\
\hline Uranium (U) & up to 5 ppm & up to 4.81 ppm & up to 2.5 ppm \\
\hline Thorium (Th) & up to 100 ppm & up to 35.8 ppm & up to 16 ppm \\
\hline Potassium (K) & up to 4.5\% & NA & up to 3\% \\
\hline & ${ }^{1}$ Sighinolfi et al., 1982 [32] ; ${ }^{2}$ Dona tti-Filho et al., 2012 [33]
\end{tabular}

In a coarse-grained rock like granite, beta-irradiation from $\mathrm{K}$ is more prone to affect intergranular fluid than the shorter-range alpha irradiation from U. Since $\mathrm{K}$ is also more pervasively distributed than $\mathrm{U}$ in granite, it can contribute to a larger scale radiolysis process.

Given the rather consistent range of $\mathrm{U}$, Th, and K concentration reported in the São Francisco Basin, we could expect in this zone a production rate of radiolytic $\mathrm{H}_{2}$ in water ranging from $10^{-8}$ to 10 ${ }^{7} \mathrm{nmol} . \mathrm{L}^{-1} . \mathrm{s}^{-1}$ (Lin et al., 2005b [35]). The methodology proposed by Sherw ood Lollar et al. (2014 [31]) to estimate the contribution of the Precambrian continental crust to $\mathrm{H}_{2}$ production via radiolysis may then be applied to infer the regional $\mathrm{H}_{2}$ flux. The total radiolytic $\mathrm{H}_{2}$ production rate in water-filled fractures of the Precambrian crust was estimated to range from 0.16 to $0.47 \times 10^{11}$ mol.yr $^{-1}$ for a corresponding surface area of $1.06 \times 10^{8} \mathrm{~km}^{2}$. Given the surface area of the Sao Francisco Basin of

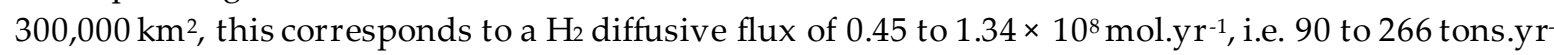
1.

\section{Production of $\mathrm{H}_{2}$ by serpentinization or hydration}

Serpentinization occurs when meteoric or oceanic w aters alter ultramafic rocks originating from the Earth's mantle, such as peridotites and volcanic rocks. These rocks undergo changes in pressure and temperature conditions, which cause them to react in presence of w ater (Schlindw ein \& Schmid, 2016 [36]; Horning et al. 2018 [37]): They are oxidized and hydrolyzed with water into serpentine, brucite and magnetite. The anaerobic oxidation of Fe(II) by the protons of $w$ ater leads to the formation of $\mathrm{H}_{2}$ (Foustoukos et al., 2008 [38]; Proskurow ski et al., 2008 [39]). In Precambrian rocks, Sherw ood Lollar et al. (2014 [31]) propose that for the totality of the Precambrian crust (i.e. $1.06 \times 10^{8} \mathrm{~km}^{2}$ ) around 0.2 to $1.8 \times 10^{11}$ mol.yr-1 of $^{-} \mathrm{H}_{2}$ are produced by hydration. Here again, rescaling these values for the 
São Francisco basin $\left(300,000 \mathrm{~km}^{2}\right)$, we obtain a $\mathrm{H}_{2}$ production rate from hydration reactions of 0.56 to $5.09 \times 10^{8}$ mol.yr ${ }^{-1}$, i.e. 113 to 1018 tons. $\mathrm{yr}^{-1}$.

Favorable conditions to produce $\mathrm{H}_{2}$ by a serpentinization process would imply the presence of low-silica mafic and ultramafic rocks as well as an optimum temperature.

Presence of ultramafic rocks

From the seismic section which crosses the São Francisco Craton from East to West (Figure 1b), the interpretations done by several authors agree on the identification of the Bambuí group (Figure 3). This unit is about 1200-1300 m deep in the area of the H2G seepage zone and lies on the Jequitaí formation which itself lies on poorly identified older Proterozoic succession, the Macaúbas and possibly the Espinhaço formations (Solon et al., 2015 [20]).
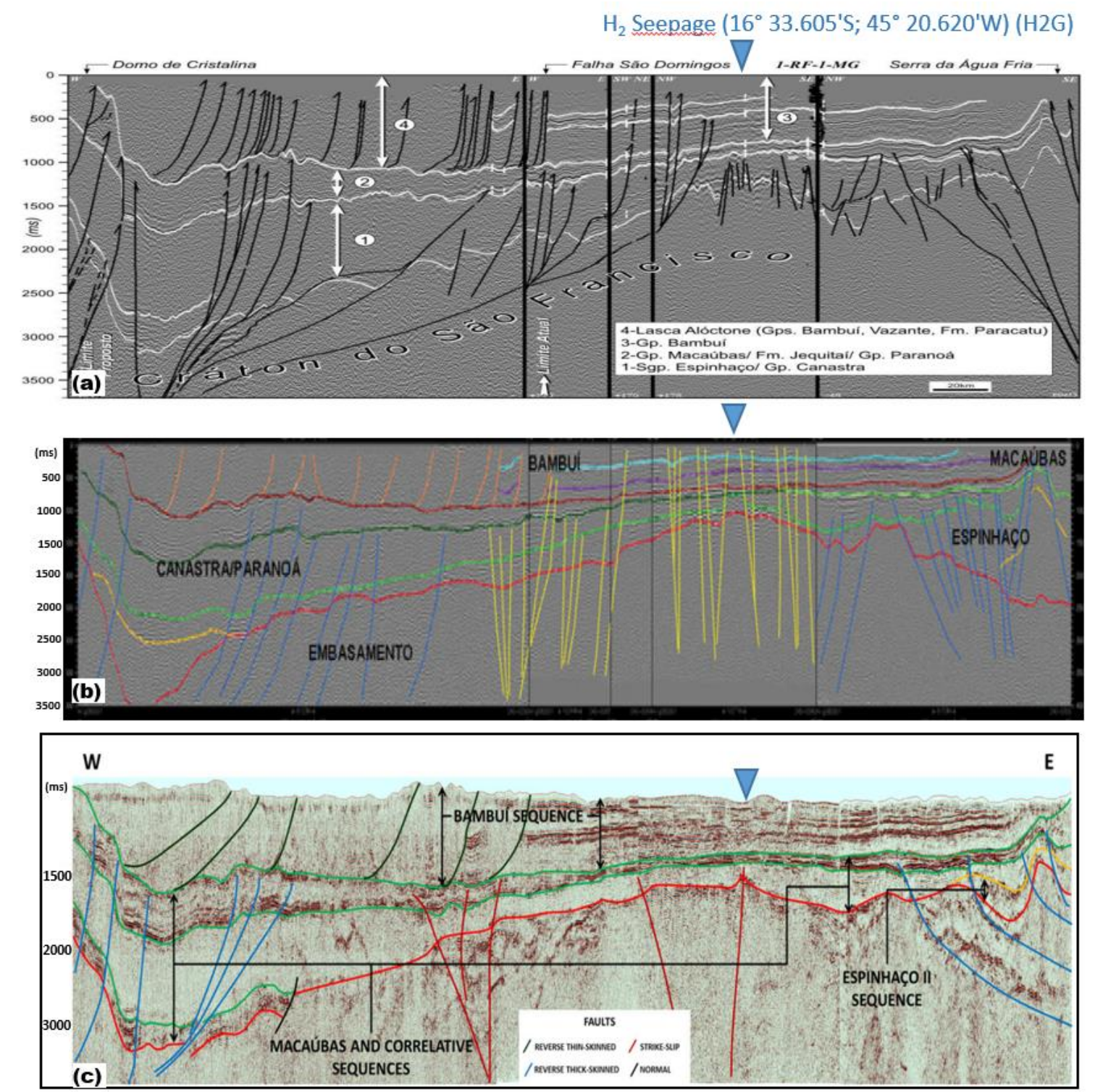

Figure 3. Three interpretations of the same reflection seis mic section across the São Francisco craton (see Figure $1 b$ for the location) from East "E" to West "W". From top to bottom: (a) Romeiro-Silva \& Zalán (2005 [24]), (b) Coelho et al. (2008 [40]) and (c) Alkmim and Martins-Ne to (2012 [41]). The locations of the exploration well A-RF-1-MG are shown in (a) and the gas seepage H2G (blue triangle) is reported for all cases. On all illustrations, the depth is expressed in two-way travel time (TWT). 
The basal Paranoá-Upper Espinhaço sequence consists of continental sediments and volcanic rocks associated with anorogenic plutons. Mesoproterozoic anorogenic magmatism associated with multiple rifting episodes might represent a manifestation of the Columbia supercontinent breakup, which started around 1.6 Ga and ended between 1.3 and 1.2 Ga (Reis et al., 2017a,b [42],[43]). The Espinhaço Supergroup is exposed on the East of the São Francisco Basin. The two basal formations of the Espinhaço sequence are composed of alluvial sandstones, conglomerates and pelites and form a ca. 300-m-thick of two coarsening-upward sequences. Despite the potential presence of K-rich alkaline volcanic and intrusives rocks (Chemal et al., 2012 [44]), this formation does not seem suitable for $\mathrm{H}_{2}$ production.

The basement rocks of the São Francisco basin are dominated by Archaean to Palaeoproterozoic migmatites, amphibolite to granulite-grade gneisses, and granite-greenstones (Teixeira et al., 2017 [22]). For example, the Rio Itapicuru low-grade supra-crustal greenstone belt has several lithostratigraphic subdivisions, including a basal mafic volcanic unit composed of massive and pillowed basaltic flows intercalated with chert, banded iron-formation, and carbonaceous shale (Oliveira et al., 2019 [45]). The banded iron-formation is mainly composed of oxidized iron Fe(III) forming a possible mix of hematite and magnetite, which can produce a strong magnetic anomaly (Pereira \& Fuck, 2005 [46]) (purple zones in Figure 4).

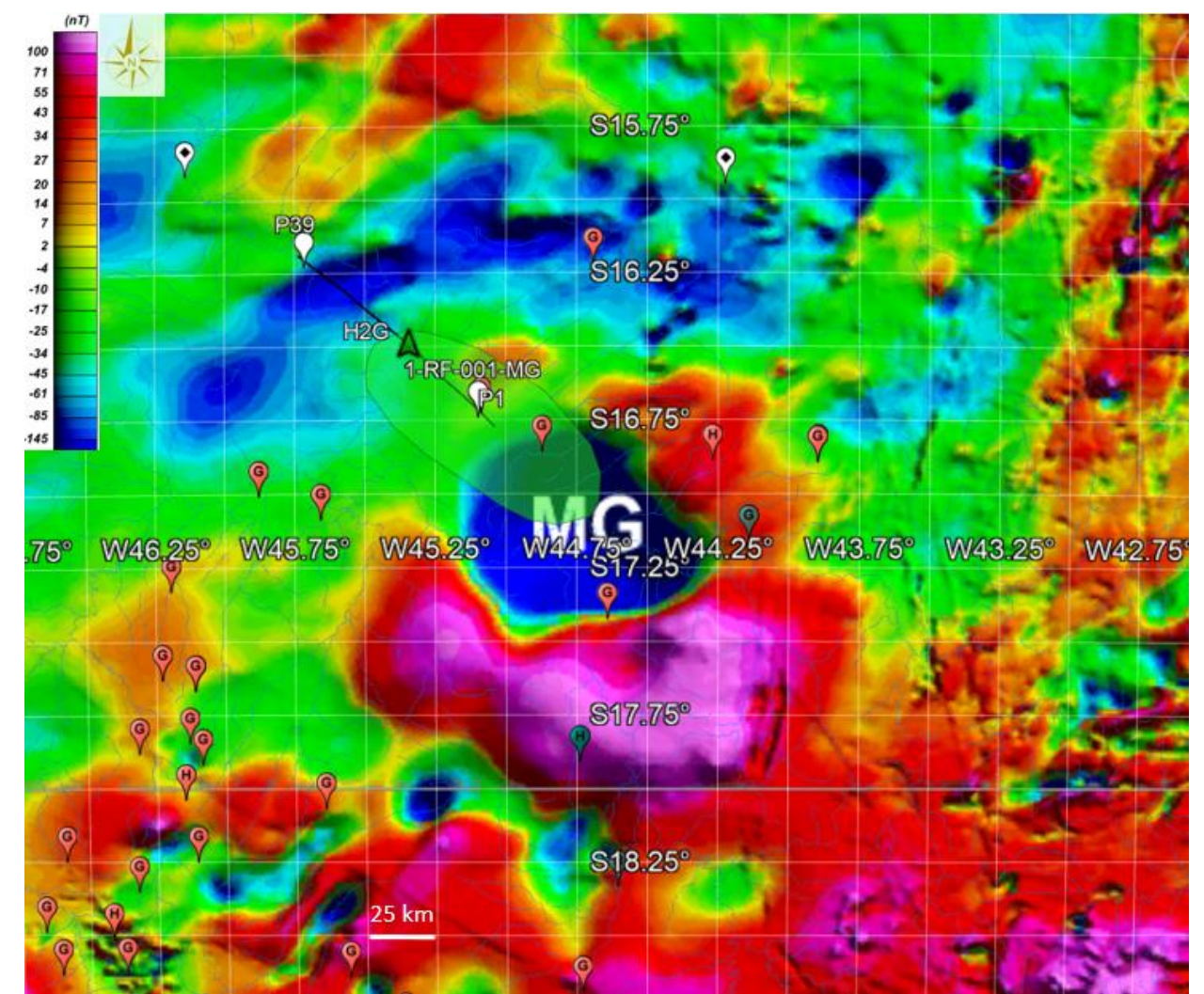

Figure 4. Magnetometric map (modified from Correa, 2019 [47]). Note that "MG" stands for "Minas Gerais".

In this area, the Bouguer anomaly map exhibits predominantly negative anomalies (Figure 5) which correlate with granitoids resulting from the crustal rejuvenation of the area, associated with partial re-fusion of the crust during past thermal events. This also suggests that major magmatic sequences affected thebasement of the southern part of the São Franscico Basin, which is compatible with the magnetic anomalies (Figure 4). Since the Quadrilátero Ferrífero (a mineral-rich region with extensive deposits of iron ore) and the "greenstone" belts present the same gravimetric signature, they could have the same origin (Pinto et al., 2007 [48]). Here again, the basement rock composition presents a high potential for $\mathrm{H}_{2}$ production. 


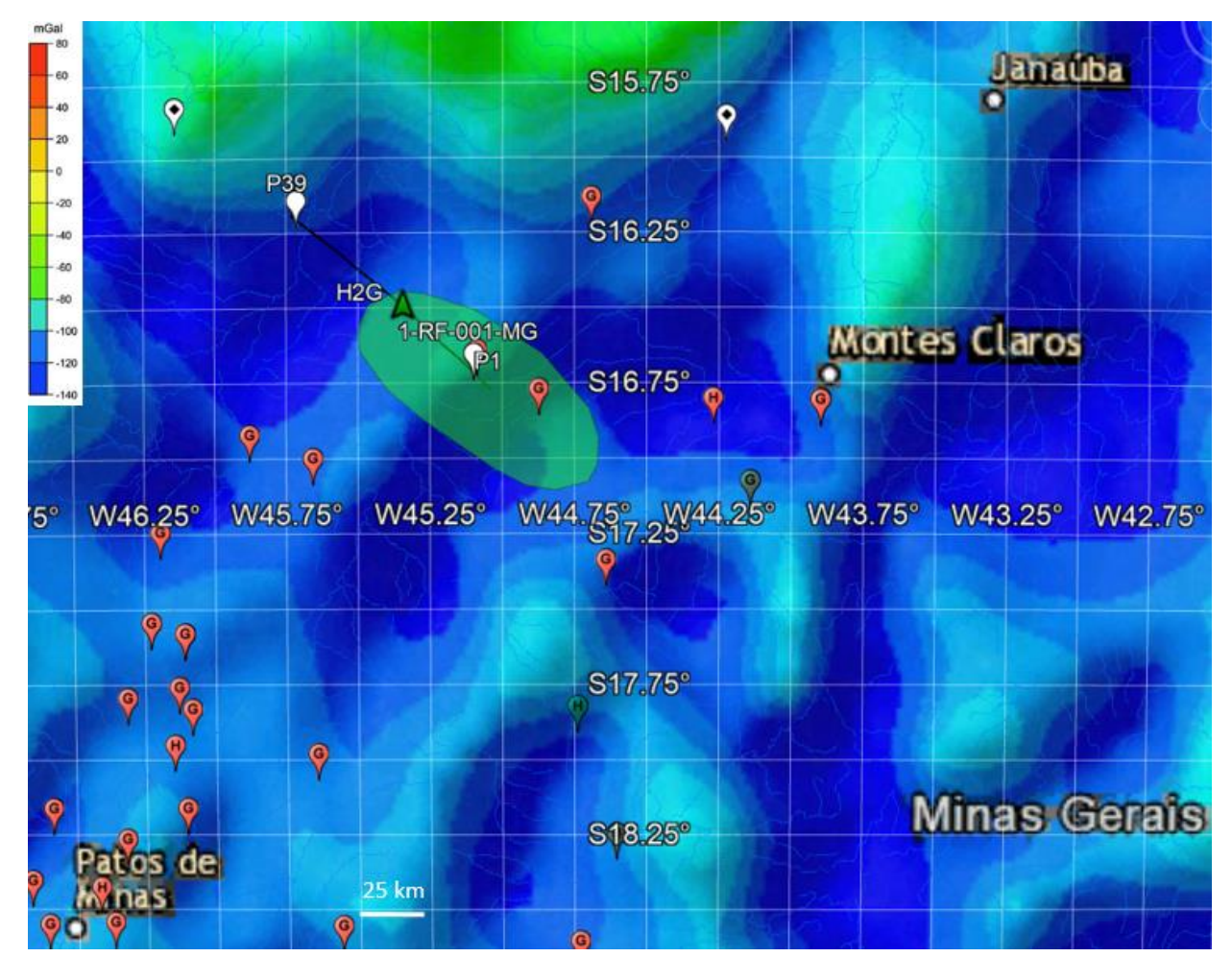

Figure 5. Bouguer anomaly map in the SãoFrancisco Basin within the studied zone (modified from Oliveira \& Andrade, 2014 [45]).

Temperature ranges at depth

The potential presence of ultramafic rocks within the area of gas seepages, could suggest a serpentinization process, but to be active, this process would require a favorable range of temperatures. Crustal thermal models have been developed to examine the implications of the observed intra-cratonic variations in heat flow across the São Francisco Basin (Alexandrino et al., 2008 [49]). The thermal models take into consideration the variation of thermal conductivity with temperature. It is thus possible to get the temperature distribution calculated along a large profile that crosses the São Francisco Basin. It turns out that our zone of interest in the São Francisco Basin, exhibits an abnormally high heat flow value for a craton (Figure 6). In the gas seepages zone (green ellipse in Figure 5), the temperature gradient is about $25^{\circ} \mathrm{C} / \mathrm{km}$ (Alexandrino et al., 2008 [49]). The optimum temperature for serpentinization $\mathrm{w}$ as found to be around $250-300^{\circ} \mathrm{C}$ with a maximum production of magnetite (Klein et al., 2013 [50]). How ever, some experimental data suggest that below $150^{\circ} \mathrm{C}, \mathrm{H}_{2}$ can still be produced through the formation of $\mathrm{Fe}^{3+}$ oxi-hydroxides (Mayhew et al., 2013 [52]; Miller et al., 2017 [53]), with the formation of $\mathrm{H}_{2}$ being possibly catalyzed by the surface of spinelstructure minerals occurring in ultramafic rocks. In such thermal conditions, $\mathrm{H}_{2}$ could be still produced at a low rate, at a depth lower than $6 \mathrm{~km}$, near the gas seepage zone, and the optimum depth for its production would be at $10-12 \mathrm{~km}$. 


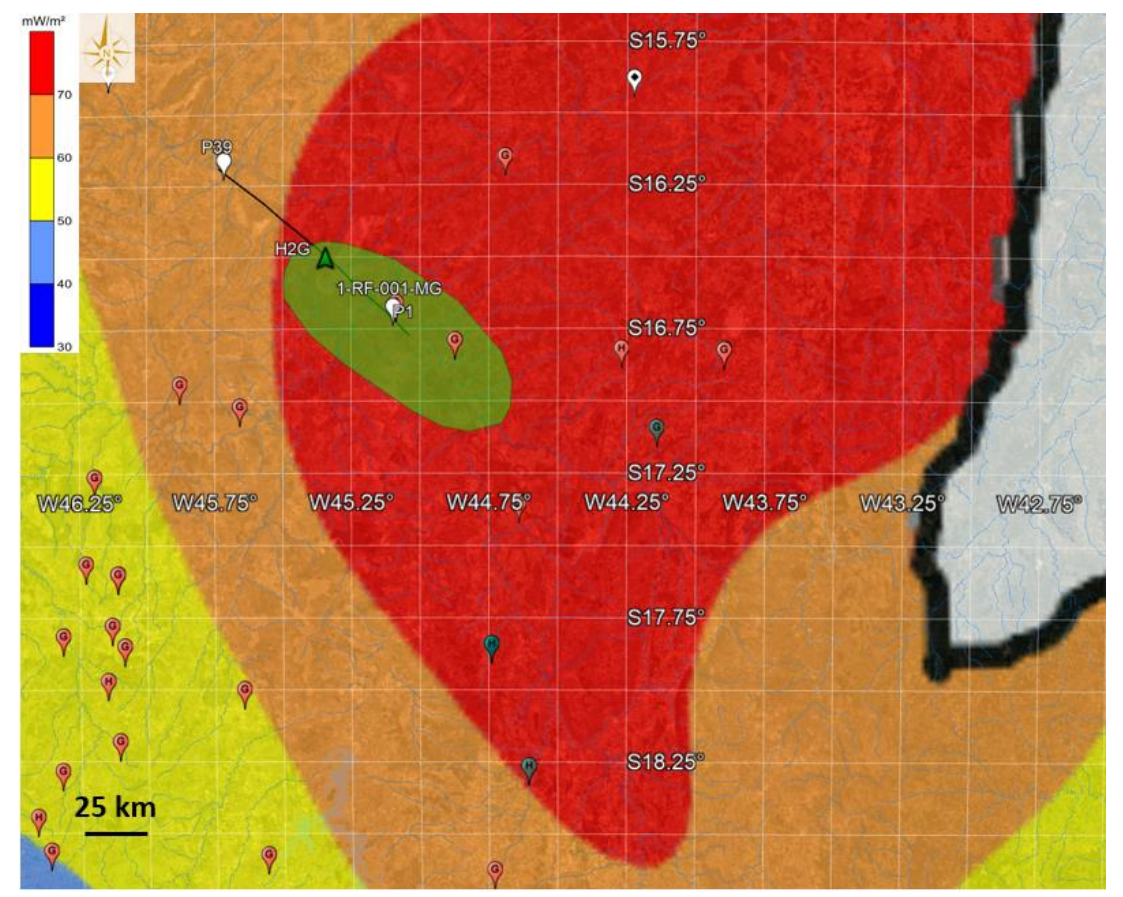

Figure 6. Heat flow map in the São Francisco Basin within the studied zone (modified from Alexandrino \& Hamza, 2012 [51]).

\section{Possible H2 bubbling at depth}

Once produced by fluid-rock interaction processes (oxidation) at depth, $\mathrm{H}_{2}$ can migrate as a dissolved component. The solubility of $\mathrm{H}_{2}$ in aqueous solutions is rather low and drops when $\mathrm{T}$ and $\mathrm{P}$ decrease when approaching the surface (Fig. 7d). The possible mechanism of $\mathrm{H}_{2}$ discharge, concentrating, and transport upw ard to the low er $\mathrm{T}-\mathrm{P}$ where $\mathrm{H}_{2}$ is less reactive is solution boiling, i.e. formation of vapor phase coexisting with the liquid phase. The concentrations of $\mathrm{H} 2$ in vapors are many orders of magnitude higher than that in the liquid (Bazarkina et al., 2020). At the same time, rock permeability is much higher for gases-rich vapors than for salt-rich liquids. Bubble formation is a function of $\mathrm{T}, \mathrm{P}$, total salinity, and gas saturation. Thus, during fluid ascent upw ard to the low er T$\mathrm{P}$, gas bubbles formation is favored (Fig. $7 \mathrm{~d}$ ). Periodicity of $\mathrm{H}_{2}$ emission at the surface reported by Prinzhofer et al. (2019) could be related to the kinetics of fluid-rock interaction at depth, further timedependent bubble accumulation, and the final periodical ejections similar to those described in geysers.

\section{Draining fault system in the São Francisco Basin}

Deep faults serve as significant channels for deep fluids to ascend into and through the crust and the ${ }^{3} \mathrm{Hel}{ }^{4} \mathrm{He}$ ratio can be used to estimate the flow rate of mantle fluids through the fault zones (Kennedy et al., 1997 [54]). Since the ${ }^{3} \mathrm{He} /{ }^{4} \mathrm{He}$ signature seems to be of crustal origin in the São Francisco basin (Flude et al., 2019 [17]), the migration path followed by the $H_{2}$ mostly crosses the sedimentary cover without major changes of the ratio value. This weak interaction with the Bambuí sequences could be due to a high flow rate value along the faults. This could be possible if the faults form direct drains from the basement to the surface assuming a sufficiently high value of permeability.

Several interpretations of the available seismic data have been proposed for the fault systems (Figure 3) (e.g. Romeiro-Silva \& Zalán, 2005 [24]; Coelho et al., 2008 [40] and Alkmim and MartinsNeto, 2012 [41]). Nevertheless, the São Francisco basin seems to encompass different tectonic elements such as the Proterozoic rift structures, Neoproterozoic foreland f-t-belts and Cretaceous rift structures (Reis \& Alkmim, 2015 [25]). The rift structure that cuts across the central portion of the 
basin is characterized by a system of major NW-SE faults. One could expect that the deep-rooted faults in the graben structures (Precambrian sequence), which have been reactivated during the Neoproterozoic Macaúbas basin-cycle, could cross most of the sedimentary formation. As a major fault system, they may control the drainage at all depth and delineate some morphological features observed on satellite imagery and digital elevation models (Reis et al., 2017b [43]).

If these faults cross different geological layers, mainly shales, sandstones and limestones, their permeability values can range from 10-19 to 10-13 $\mathrm{m}^{2}$ (Donzé et al., 2020 [55]). In terms of hydraulic conductivity for the water carrying the gas and neglecting the contribution of temperature, this could correspond to a value as high as $10^{-6} \mathrm{~m} / \mathrm{s}$. This means that in the fastest scenario, the fluid could take less than 100 years to migrate across the Bambuí sedimentary layer through a fault system.

\section{Possible temporary shallow zones of $\mathrm{H}_{2}$ accumulation}

The pressure variation observed at $1 \mathrm{~m}$ depth in the São Franciscobasin (Prinzhofer et al., 2019 [15]), with a momentary increase in $\mathrm{H}_{2}$ pressure could indicate that the $\mathrm{H}_{2}$ systems are active. There is only a small temperature window where $\mathrm{H}_{2}$ may remain stable over a long time. This window corresponds to a $\mathrm{T}$ range where abiotic redox reactions such as thermochemical sulfate reduction or carbonate reduction (e.g. Fisher Tropsh type reaction) are slow (Truche et al., 2009 [56]), and where bacteria are inactive. Such a $\mathrm{T}$ range can be roughly approximated to be $100-200{ }^{\circ} \mathrm{C}$. Since these temperature conditions are not met at shallow depth, $\mathrm{H}_{2}$ will probably not survive to long residence time. Despite this fact, previous studies of $\mathrm{H}_{2}$ seepages often indicate that the hydrogen systems are active, and transient accumulations of hydrogen at relatively shallow depth can be observed (Prinzhofer et al., 2018 [14], Goebel et al., 1984 [28]; Guélard et al., 2017 [26]). These observations may suggest a constant recharge of the aquifers by $\mathrm{H}_{2}$ flowing from deeper levels of the basin.

The circular depression where $\mathrm{H}_{2}$ seepage is observed (Figure $2 b$ ) could be related to a sinkhole structure resulting from a chemical dissolution process at depth. If so, these depressions will contain standing water connected with a ground-w ater reservoir contained in karst (De Carvalho et al., 2014 [57]). The presence of resistive carbonate and calcareous rocks was inferred from $\sim 320 \mathrm{~m}$ to $\sim 480 \mathrm{~m}$ followed by a layer of intercalated shales and sandstones (Solon et al., 2015 [20]). This carbonate layer which corresponds to the Lagoa do Jacaré carbonate layer, exhibits a potential karst system according to the outcrops located East of the São Francisco Basin (Dos Santos et al., 2018 [58]).

Assuming a karst system at depth, this could imply a high level of porosity favorable for a massive storage volume of an aquifer. Since karst features are controlled by structural heterogeneities, such as faults and fractures, which influence fluid flow, they can provide preferential pathways for geofluids with the development of secondary porosity. This could agree with the fact that the circular depressions where $\mathrm{H}_{2}$ is venting are aligned along a major fault (Cathles \& Prinzhofer, 2020 [16]).

\section{Putting it all together: A potential $\mathrm{H}_{2}$ system within the São Francisco basin}

The first key point is related to potential source areas, e.g. the presence of both ultramafic and U, Th, K-rich rocks. The presence of Archean greenstone belts containing ultramafic rocks, TTG, migmatites and K-rich granitic plutons represent excellent $\mathrm{H}_{2}$-producing zones either via serpentinization, or water radiolysis. Magnetic (Figure 4) and Bouguer (Figure 5) anomalies are compatible with the presence of ultramafic rock producing $\mathrm{H}_{2}$. Temperature conditions also seem favorable for the serpentinization process: with a temperature gradient of $25^{\circ} \mathrm{C} / \mathrm{km}$ (Alexandrino et al., 2008 [49]), the optimum range of temperature would be expected at a depth of $10 \mathrm{~km}$, with possiblelower rate processes at a shallower depth.

The second key point is the structural/tectonic context and the presence of faults deeply rooted in the basements capable of draining a potential deep and scattered source. All interpretations of the seismic profile of the zone of interest, suggest the presence of deep faults following the graben structures (Figure 3): they can be able to drain hydrogen produced at depth where the PressureTemperature conditions are optimal. Some interpretations suggest that some of these faults could cross the entire sedimentary sequence (Coelho et al., 2008 [40]), producing gas seepages directly at the surface. Some others predict that these faults could reach some potential shallow carbonated 
reservoirs (Romeiro-Silva \& Zalán, 2005 [24]). These deep faults could also only reach the unconformity zone which composes the boundary between the sedimentary basin and basement (Alkmim \& Martins-Neto, 2012 [41]).

The third key point concerns the storage areas (i.e. reservoirs) of $\mathrm{H}_{2}$ at depth. As mentioned previously, the interface between the basement rocks and the sedimentary layers could represent a potential zone of accumulation. The interface is composed of the Macaúbas and the Espinhaço formations. The Macaúbas sequence is made up of sandstones, pelites, diamictites, carbonates, basic volcanic rocks, and metamorphosed banded iron formations (Alkmim et al., 2012 [41]) whereas the Espinhaço formation is a quartz-arenite dominated package. The presence of the Paranoá-Upper Espinhaço quartzite, which is tectonically uplifted, can facilitate the occurrence of sandstone reservoirs with appreciable permeability and porosity. Thus, potential reservoir rocks could be found among siliciclastics of the Macaúbas-Paranoá Megasequence (Solon et al., 2015 [20]).

An interesting characteristic of the deep topography is that the seepage zone H2G is located near the apex of the basement rock in the central part of the basin (see Figure 3). As the $\mathrm{H}_{2}$ charged fluid reaches the Macaúbas/Espinhaço formations, it migrates along the unconformity tow ard this highest point before escaping to the surface in the green seepage zone (Figure 2). On its way to the surface, $\mathrm{H}_{2}$ can also be temporarily trapped in the Sete Lagoas formation and at a shallower depth, inside Lagoa do Jacaré formation. The permeability value of the Sete Lagoas Larst aquifer formation is estimated to range between $10^{-14} \mathrm{~m}^{2}$ and 10-9 $\mathrm{m}^{2}$ (Galvão et al., 2015 [59]). As for the Lagoa do Jacaré formation very low permeability and porosity values were found in the Petrobras well 1-RF-1-MG. The presence of faults, possibly connecting all these reservoirs with the surface could explain the apparent structural control on the distribution of the known gas seepages (Curto et al., 2012 [19]). Nevertheless, the presence of sinkholes in the H2G seepage area suggests the existence of a shallow local karst formation, which could constitute a temporary reservoir for $\mathrm{H}_{2}$.

Thus, surface seepages may be either in connection with the source rock or with intermediate leaking reservoirs since these tw o configurations are present in this area. A summary of $\mathrm{H}_{2} \mathrm{migration}$ from sources to seeps in the São Franciscobasin is presented in Figure 7.

\section{Discussing the $\mathrm{H}_{2}$ production from radiolysis and hydration reactions in the São Francisco Basin}

Combining the $\mathrm{H}_{2}$ production rate from water radiolysis and hydration reaction assessed in the previous sections, we obtain an estimate of 1.01 to $6.43 \times 10^{8} \mathrm{~mol}_{\text {.yr }} \mathrm{r}^{-1} \mathrm{H}_{2}$ production i.e. $\sim 200$ to 1300 tons.yr-1 (Table 3). Cathles and Prinzhofer (2020 [20]) considered the local flux rate in the H2G seepage zone (Figure $2 \mathrm{~b}$ ) to range from 7000 to $178,000 \mathrm{~m}^{3}$ per day. At a temperature of $21^{\circ} \mathrm{C}$ and a pressure of $1 \mathrm{~atm}$, these values correspond to 0.105 to $3.68 \times 10^{9} \mathrm{~mol}_{\mathrm{yr}}^{-1}$, i.e. 213 to 5400 tons.yr $^{-1}$ (Table 3). Since the expulsion rate of $\mathrm{H}_{2}$ is almost certainly not steady, the episodic ratemeasured in the $\mathrm{H} 2 \mathrm{G}$ vent might be overestimated.

In comparison, on the Mid-Atlantic Ridge (MAR), the total $\mathrm{H}_{2}$ discharge at the Rainbow hydrothermal field is estimated to be $\sim 10^{8}$ moles $\mathrm{H}_{2}$ per year, i.e. $\sim 200$ tons.yr ${ }^{-1}$ (Charlou et al., 2010 [61]) (Table 3). At a larger scale, the $\mathrm{H}_{2}$ flux from all high-temperaturebasaltic vents along the MAR has been estimated at $10^{9}-10^{10}$ mol. $\mathrm{yr}^{-1}$, whereas the $\mathrm{H}_{2}$ flux from high-temperature ultramafic vents along the Mid-Oceanic Ridge (MOR) has been estimated at $10^{10}-10^{11}$ mol.yr-1 (Table 3) (Keir, 2010 [62]; Cannat et al., 2010 [63]), i.e. 20,000 to 200,000 ton.y ${ }^{-1}$.

According to our calculations, which are based on the model developed by Sherwood Lollar et al. (2014 [31]) for the Precambrian continental lithosphere, the maximum $\mathrm{H}_{2}$ production rate from the basement rocks of the São Francisco Basin is within the same order of magnitude as the $\mathrm{H}_{2}$ flux of one sinkhole of $500 \mathrm{~m}$ in diameter ( $\mathrm{H} 2 \mathrm{G}$ zone). This latter $\mathrm{H}_{2}$ venting site w ould also represent from $0.047 \%$ to $7.5 \%$ of the global estimated $\mathrm{H}_{2}$ production from the Precambrian continental Lithosphere. This large discrepancy in the results leads us to conclude that there is a need to increase the accuracy of hydrogen flux estimates through long term monitoring of soil gas migration according to different methodologies and/or to revisit the global models. 
Table 3. Estimated $\mathrm{H}_{2}$ flow rate production (tons. $\mathrm{yr}^{-1}$ )

\begin{tabular}{|c|c|c|c|}
\hline System & $\times 10^{9}$ mol.yr $^{-1}$ & tons.yr ${ }^{-1}$ & Reference \\
\hline $\begin{array}{l}\text { São Francisco basin } \\
\text { (radiolysis \& hydration } \\
\text { combined) }\end{array}$ & $0.101-0.643$ & $204-1284$ & This study \\
\hline $\begin{array}{l}\text { H2G seepage zone São } \\
\text { Francisco basin }\end{array}$ & $0.105-3.68$ & $213-5400$ & $\begin{array}{l}\text { From Cathles \& } \\
\text { Prinzhofer, } 2020 \text { [16] }\end{array}$ \\
\hline $\begin{array}{l}\text { Rainbow hydrothermal } \\
\text { field }\end{array}$ & $\sim 0.1$ & 200 & Charlou et al., 2010 [61] \\
\hline $\begin{array}{l}\text { Ultramafic vents along the } \\
\text { Mid-Oceanic ridges }\end{array}$ & $\sim 10-100$ & $20,000-200,000$ & $\begin{array}{ll}\text { Keir, } 2010 \text { [62]; } & \text { Cannat } \\
\text { et al., 2010 [63] } & \\
\end{array}$ \\
\hline $\begin{array}{l}\text { Global Precambrian } \\
\text { continental lithosphere: } \\
\text { (radiolysis \& hydration } \\
\text { combined) }\end{array}$ & $36-227$ & $72,000-454,000$ & $\begin{array}{l}\text { Sherw ood Lollar et al., } \\
2014 \text { [31] }\end{array}$ \\
\hline
\end{tabular}



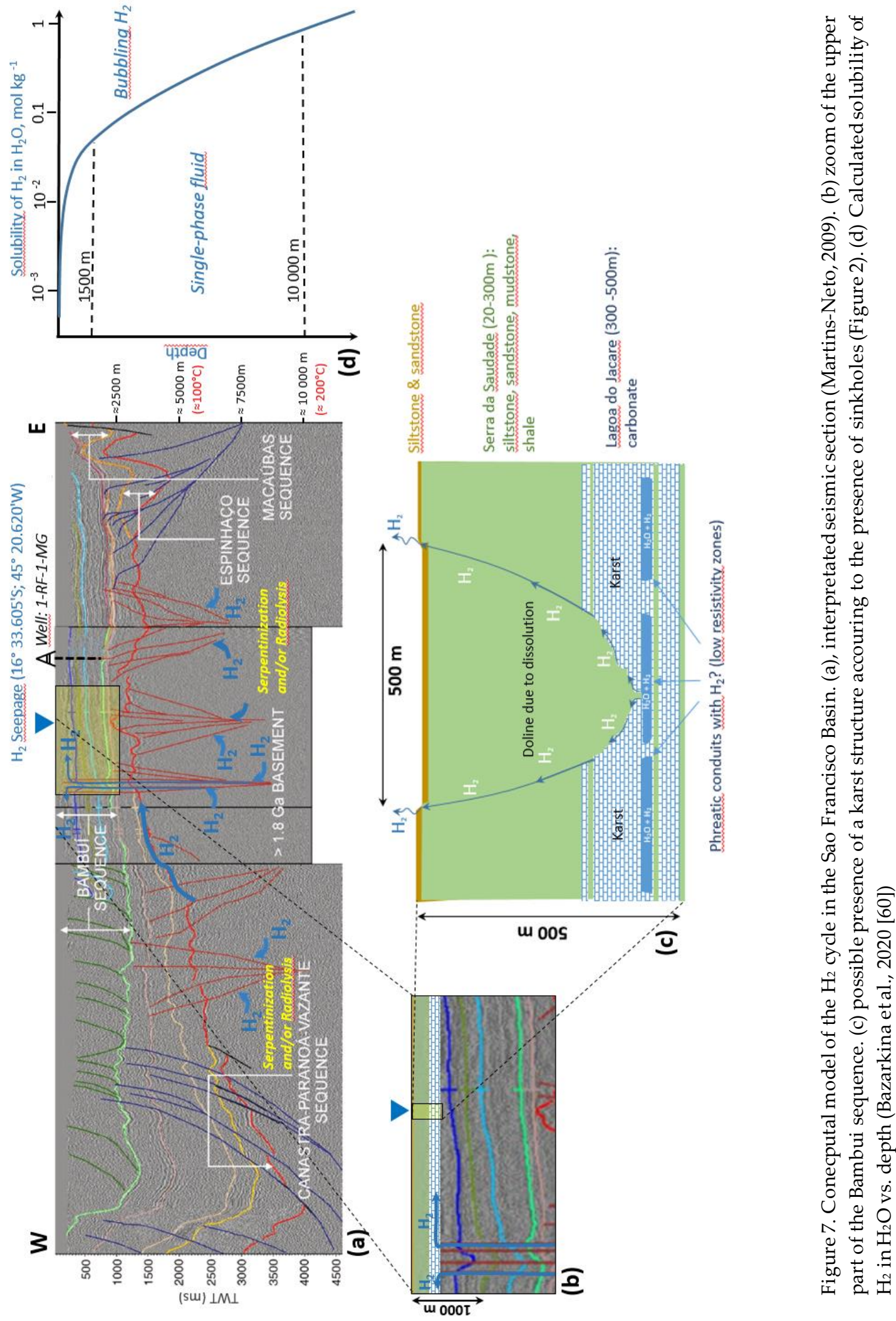

\section{Conclusion}

Hydrogen exploration requires a combination of the techniques and data used for both conventional petroleum and mining exploration. The first elementary bricks we provide here to 
evaluate the sources, migration and trapping are certainly not enough, but the following general guidelines will be extremely valuable to target fertile $\mathrm{H}_{2}$ area in intra-cratonic areas.

- Explore in old provinces where basement rocks are Archean to Paleoproterozoic. Use lithologies (ultramafic rocks, U-, Th-, K-rich rocks), and $\mathrm{He}$ (R/Ra) as pathfinders for the $\mathrm{H}_{2}$ generation potential. - Consider carefully the local geothermal gradient as it may be of use to infer fertile zones for active serpentinization.

- Identify location of faults deeply rooted in the basement such as horst and graben structures. Pay attention to the topography of the unconformity, which represent both a major drainage and trapping area.

- Target relatively shallow traps. As for $\mathrm{He}, \mathrm{H}_{2}$ partitions into gas better at shallow depth. Surface rounded depressions, karsts and sinkholes seems to represent favorable collecting zones prior $\mathrm{H}_{2}$ escapes into the atmosphere. A field investigation based on electromagnetic and gravimetric prospections could help to characterize the structure of the sinkhole at depth in order to set up a geotechnical drilling at the right location. Such borehole carried out on the first hundreds of meters could provide valuable information on the $\mathrm{H}_{2}$ concentration gradient down to the upper karstic formation, which is often not possible from classical oil and gas exploration well drilling.

Dedicated exploration boreholes are definitely required to improve this preliminary exploration guide and to strengthen the accuracy for $\mathrm{H}_{2}$ flux measurements. Additional constraints on the $\mathrm{H}_{2}$ accompanying gases $\left(\mathrm{He}, \mathrm{N}_{2}, \mathrm{Ne}\right.$, Hydrocarbons, $\mathrm{Rn}$ ) and on the role of $\mathrm{H}_{2}$-consuming microbial communities at the subsurface within the emitting structure (Myagkiy et al., 2020) [64] will be extremely valuable.

Acknowledgments: Grateful thanks to Guest Editor Pr. Lawrence Cathles and 2 anonymous re vie wers for their constructive reviews. The first author would like to thank Dr. Sophie-Adélaïde Magnierfor helpful discussions. Laurent Truche gra tefully a cknowle dge the support from the Institut Universitaire de France.

Author Contributions: All authors contributed to the writing of the paper. All authors have read and agreed to the published version of the manuscript.

Funding: The work reported here was not supported by any grant by any agency.

Conflicts of Interest: The authors declare no conflicts of interest.

\section{References}

1. Truche, L., McCollom, T. M., \& Martinez, I. (2020). Hydrogen and Abiotic Hydrocarbons: Molecules that Change the World. Elements: An International Magazine of Mineralogy, Geochemistry, and Petrology, $16(1), 13-18$.

2. Smith N.J.P. (2002), It's time for explora tionists to ta ke hydrogen more seriously. First Break 20: 246-253

3. Smith N.J.P., Shepherd T.J., Styles M.T., Williams G.M. (2005) Hydrogen exploration: a review of global hydrogen accumulations and implications for prospective areas in NW Europe. In: Doré AG, Vining BA (eds) Petrology Geology: North-West Europe and Global Perspectives - Proceedings of the 6th Petroleum Geology Confe rence. Geological Society, London. Petroleum Geology Conference Series 6: 349-358

4. Truche, L., \& Bazarkina, E. F. (2019). Natural hydrogen the fuel of the 21st century. In E3S Web of Conferences (Vol. 98, p. 03006). EDP Sciences. 
5. Gaucher, E. C. (2020). New Perspectives in the Industrial Exploration for Native Hydrogen. Elements: An International Magazine of Mine ralogy, Geochemistry, and Petrology, 16(1), 8-9.

6. Zgonnik, V. (2020). The occurrence and geoscience of natural hydrogen: A comprehensive review. EarthScience Reviews, 103140.

7. Neal, C., \& Stanger, G. (1983). Hydrogen generation from mantle source rocks in Oman. Earth and Planetary Science Letters, 66, 315-320.

8. Coveney, R. M.Jr., E. D. Goebel, E. J. Zeller, and E. E. Angino (1987), Serpentinization and the origin of hydrogen gas in Kansas, AAPG Bull., 71, 39- 48.

9. Abrajano, T.A., Sturchio, N.C., Kennedy, B.M., Lyon, G.L., Muehlenbachs, K., Bohlke, J.K., 1990. Geochemistry of reduced gas related to serpentinization of the Zambales ophiolite, Philippines. Appl Geochem. 5, 625-630.

10. Charlou, J.L., Fouquet, Y, Donval, J.P., Auzende, JM, Jean-Baptiste, P, Stievenard, M., 1996. Mineral and gas chemistry of hydrothermal fluids on an ultrafast spreading ridge: East Pacific Rise, $17^{\circ}$ to $19^{\circ} \mathrm{S}$ (Naudur cruise, 1993) phase separation processes controlled by volcanic and tectonic activity. J Geophys Res 101, 899-919

11. Seewald J.S., Cruse A, Saccocia P (2003) Aqueous volatiles in hydrothermal fluids from the Main Endeavour Field, northern Juan de Fuca Ridge: te mporal variability following earthquake activity. Earth and Planetary Science Letters 216:575-590

12. Larin, N., Zgonnik, V., Rodina, S., Deville, E., Prinzhofer, A., \& Larin, V. N. (2015). Natural molecular hydrogen seepage associated with surficial, rounded depressions on the European craton in Russia. Natural Resources Research, 24(3), 369-383.

13. Zgonnik, V., Beaumont, V., Deville, E., Larin, N., Pillot, D., \& Farrell, K. M. (2015). Evidence for natural molecular hydrogen seepage associated with Carolina bays (surficial, ovoid depressions on the Atlantic Coastal Plain, Province of the USA). Progress in Earth and Planetary Science, 2(1), 31.

14. Prinzhofer, A., Cissé, C. S. T., \& Diallo, A. B. (2018). Discovery of a large a ccumula tion of na tural hydrogen in Bourakebougou (Mali). International Journal of Hydrogen Energy, 43(42), 19315-19326.Reis, H. L., \& Alkmim, F. F. (2015). Ana tomy of a basin-controlled foreland fold-thrust belt curve: The Três Marias salient, São Franciscobasin, Brazil. Marine and Pe troleum Geology, 66, 711-731.

15. Prinzhofer, A., Moretti, I., Francolin, J., Pacheco, C., d'Agostino, A., Werly, J., \& Rupin, F. (2019). Natural hydrogen continuous emission from sedimentary basins: The example of a Brazilian $\mathrm{H}_{2}$-e mitting structure. International Journal of Hydrogen Energy, 44(12), 5676-5685.

16. Cathles, L., \& Prinzhofer, A. (2020). What Pulsating H2 Emissions Suggest about the H2 Resource in the São Francisco Ba sin of Brazil. Geosciences, 10(4), 149.

17. Flude, S. ,Warr, O., Magalhães, N., Bordmann, V., Fleury, J. M., Re is, H.L.S., Trinda de, R.I., Hille gonds, D., Sherwood Lollar, B., Ballentine, C. J. (2019). Deep crustal source for hydrogen and helium ga ses in the São Francisco Basin, Minas Gerais, Brazil. AGUFM, 2019, EP51D-2111.

18. Heilbron, M., Cordani, U. G., \& Alkmim, F. F. (2017). The São Francisco craton and its margins. In São Francisco Craton, Eastern Brazil (pp.3-13). Springer, Cham.

19. Curto, J. B., Pires, A. C., Silva, A. M., \& Crósta, Á. P. (2012). The role of airborne geophysics for de tecting hydrocarbon microseepages and related structural features: The case of Remanso do Fogo, Brazil. Geophysics, 77(2), B35-B41.

20. Solon, F. F., Fontes, S. L., \& Meju, M. A. (2015). Magnetotelluric imaging integrated with seismic, gra vity, magnetic and well-log data for basement and carbonate reservoir mapping in the São Francisco Basin, Brazil. Petroleum Geoscience, 21(4), 285-299.

21. Anhaeusser, C. R. (2014). Archaean greenstone belts and associated granitic rocks -a re view. Journal of African Earth Sciences, 100, 684-732.

22. Teixeira, W., Oliveira, E. P., \& Marques, L. S. (2017). Nature and evolution of the Archean crust of the São Francisco Craton. In São Francisco Craton, Eastern Bra zil (pp. 29-56). Springer, Cham.

23. Delpomdor, F. R., Ilambwetsi, A. M., Caxito, F. A., \& Pedrosa-Soares, A. C. (2020). New interpretation of the basal Bambuí Group, Sete Lagoas High (Minas Gerais, SE Brazil) by sedimentological studies and regional implications for the aftermath of the Marinoan glacia tion: Correlations across Brazil and Central Africa. Geologica Belgica.

24. Romeiro-Silva, P. C., \& Zalán, P. V. (2005). Contribuição da sísmica de reflexão na de terminação do limite oeste do Cráton do São Francisco. III Simpósio sobre o Cráton do São Francisco, Short Papers, 44-47. 
25. Reis,H. L., \& Alkmim, F. F. (2015). Ana tomy of a ba sin-controlled foreland fold-thrust belt curve: The Três Marias salient, São Francisco basin, Brazil. Marine and Petroleum Geology, 66, 711-731.

26. Guélard, J., Beaumont, V., Rouchon, V., Guyot, F., Pillot, D., Jézéquel, D., Ader, M., Ne well, K.D. \& Deville, E. (2017). Natural H2 in Kansas: Deep or shallow origin? Geochemistry, Geophysics, Geosystems, 18(5), 1841-1865.

27. Lin, L. H., Hall, J., Lippmann-Pipke, J., Ward, J. A., Sherwood Lollar, B., DeFlaun, M., Rothmel. R., Moser, D., Gihring T.M., Mislowack, B., \& Onstott, T. C. (2005a). Radiolytic H2 in continental crust. nuclear power for deep subsurface microbial communities. Geochemistry, Geophysics, Geosystems, 6(7).

28. Goebel, E. D., R. M. J. Coveney, E. E. Angino, E. J. Zeller, and G. A. M. Dreschhoff (1984), Geology, composition, isotopes of na turally occurring H2/N2 rich gas from wells near Junction City, Kansas, Oil Gas J., 82(19), 215- 222.

29. Lollar, B. S., Onstott, T. C., Lacrampe-Couloume, G., \& Ballentine, C. J. (2014). The contribution of the Precambrian contine ntal lithos phe re to globalH2 production. Nature, 516(7531), 379-382.

30. Parnell, J., \& Blamey, N. (2017). Global hydrogen reservoirs in basement and basins. Geochemical transactions, 18(1), 2.

31. Sherwood Lollar B., Onstott T.C., Lacrampe-Couloume G., Ballentine C.J. (2014) The contribution of the Precambrian continental lithos phere to global $\mathrm{H} 2$ production. Na ture 516:379-382

32. Sighinolfi, G. P., Figueredo, M. C. H., Fyfe, W. S., Kronberg, B. I., \& Oliveira, M. T. (1982). Geochemistry and petrology of the Jequie granulitic complex (Brazil): an Archean basement complex. Contributions to Mine ralogy and Petrology, 78(3), 263-271.

33. Donatti-Filho, J. P., Tappe, S., Oliveira, E. P., \& Heaman, L. M. (2013). Age and origin of the Neoprote rozoic Brauna kimberlites: Melt generation within the metasomatized base of the São Francisco craton, Brazil. ChemicalGeology, 353, 19-35.

34. Reis, H. L. S., Barbosa, M. S. C., Alkmim, F. F. D., \& Soares, A. C. P. (2012). Magnetometric and gamma spectrometric expression of southwe stern São Francisco Basin, Se rra Selada quadrangle (1: 100.000), Minas Gerais state.

35. Lin, L. H., Slater, G. F., Lollar, B. S., La crampe-Couloume, G., \& Onstott, T. C. (2005b). The yield and is otopic composition of radiolytic $\mathrm{H} 2$, a potentialenergy source for the deep subsurface biosphere. Geochimica et Cosmochimica Acta, 69(4), 893-903.

36. Schlindwein, V., \& Schmid, F. (2016). Mid-ocean-ridge seismicity reveals extreme types of ocean lithos phere. Nature, 535(7611), 276-279.

37. Horning, G., Sohn, R. A., Canales, J. P., \& Dunn, R. A. (2018). Local se is micity of the rainbow massif on the Mid-Atlantic Ridge. Journal of Geophysical Research: Solid Earth, 123(2), 1615-1630.

38. Foustoukos, D. I., Savov, I. P., \& Janecky, D. R. (2008). Chemical and isotopic constraints on water/rock interactions at the Lost City hydrothermal field, $30 \mathrm{~N}$ Mid-Atlantic Ridge. Geochimica et Cosmochimica Acta, 72(22), 5457-5474.

39. Proskurowski, G., Lilley, M. D., Seewald, J. S., Früh-Green, G. L., Olson, E. J., Lupton, J. E., Sylva, S.P., \& Kelley, D. S. (2008). Abiogenic hydrocarbon production at Lost City hydrothermal field. Science, 319(5863), 604-607.

40. Coelho, J. C. C., Martins-Neto, M. A., \& Marinho, M. S. (2008). Estilos estruturais e evolução tectônica da porção mineira da ba cia proterozóica do São Francisco. Revista Brasileira de Geociências, 38(2 suppl), 149 165.

41. Alkmim, F. F., \& Martins-Neto, M. A. (2012). Proterozoic first-order sedimentary sequences of the São Francisco craton, eastern Brazil. Marine and Petroleum Geology, 33(1), 127-139.

42. Reis, H. L., Suss, J. F., Fonseca, R. C., \& Alkmim, F. F. (2017a). Ediacaran forebulge grabens of the southern São Francisco basin, SE Brazil: Craton interior dynamics during West Gondwana assembly. Precambrian Research, 302, 150-170.

43. Reis, H. L., Alkmim, F. F., Fonseca, R. C., Nascimento, T. C., Suss, J. F., \& Prevatti, L. D. (2017b). The São Francisco Basin. In São Francisco Craton, Eastern Brazil (pp. 117-143). Springer, Cham.

44. Chemale Jr, F., Dussin, I. A., Alkmim, F. F., Martins, M. S., Queiroga, G., Armstrong, R., \& Santos, M. N. (2012). Unravelling a Proterozoic basin history through detrital zircon geochronology: the case of the Es pinhaço Supergroup, Minas Gerais, Brazil. Gondwana Research, 22(1), 200-206. 
45. Oliveira, R.G., Andrade, J.B.F., 2014. Interpretação Geofísica dos Principais Domínios Tectônicos Brasileiros. In: Silva, M.G., Rocha Neto, M.B., Jost, H., Kuyumjian, R. M. (Orgs.). Metalogênese da Províncias Tectônicas Brasileiras. 1ed. Rio de Janeiro: CPRM-Serviço Geológico do Brasil, v. 1, p. 21-38.

46. Pereira, R.S., \& Fuck, R. A. (2016). Archean nucleii and the distribution of kimberlite and related rocks in the São Francisco craton, Brazil. Revista Brasileira de Geociências, 35(4 sup), 93-104.

47. Correa, R.T. (2019). Mapa da anomalia magnética do Brasil (terceira edição ). Escala 1:5.000.000. Bra sília, SGB-CPRM - Serviço Geológico do Brasil.

48. Pinto, L. G. R., Ussami, N., \& Sá, N. C. D. (2007). Aquisição e interpretação de anomalias gra vimétricas do Quadrilátero Ferrífero, SE do Cráton SãoFrancisco. Revista Brasileira de Geofísica, 25(1), 21-30.

49. Alexandrino, C. H., \& Hamza, V. M. (2008). Estimates of heat flow and heat production and a thermal model of the São Francisco craton. International Journal of Earth Sciences, 97(2), 289-306.

50. Klein F, Bach W, McCollom TM (2013) Compositional controls on hydrogen generation during serpentinization of ultrama fic rocks. Lithos 178: 55-69

51. Alexandrino, C. H., \& Ha mza, V. M. (2012) Improved a ssessment of Deep Crustal Ther mal Field based on Joint Inversion of Heat Flow, Elevation and Geoid Anomaly data.

52. Mayhew, L. E., Ellison, E. T., McCollom, T. M., Trainor, T. P., \& Templeton, A. S. (2013). Hydrogen generation from low-temperature water-rock reactions. Nature Geoscience, 6(6), 478-484.

53. Miller, H. M., Mayhew, L. E., Ellison, E. T., Kelemen, P., Kubo, M., \& Templeton, A. S. (2017). Low temperature hydrogen production during experimental hydration of partially-serpentinized dunite. Geochimica et Cosmochimica Acta, 209, 161-183.

54. Kennedy, B. M., Kharaka, Y. K., Evans, W. C., Ellwood, A., DePaolo, D. J., Thordsen, J., Ambats, G. \& Mariner, R. H. (1997). Mantle fluids in the San Andreas fault system, California. Science, 278(5341), 12781281.

55. Donzé, F. V., Tsopela, A., Guglielmi, Y., Henry, P., \& Gout, C. (2020). Fluid migration in faulted shale rocks: channeling below active faulting thre shold. Europe an Journal of Environmental and Civil Enginee ring, 1 15.

56. Truche, L. (2009). Transformations minéralogiques et géochimiques induites par la présence d'hydrogène dans un site de stockage de déchets radioactifs (Doctoral dissertation, Université de Toulouse, Université Toulouse III-PaulSabatier).

57. De Carvalho, O. A., Guimarães, R. F., Montgomery, D. R., Gille spie, A. R., Trancoso Gomes, R. A., de Souza Martins, É., \& Silva, N. C. (2014). Karst depression detection using ASTER, ALOS/PRISM and SRTMderive digital elevation models in the Bambuí Group, Brazil. Remote Sensing, 6(1), 330-351.

58. Dos Santos, D. M., Sanchez, E. A., \& Santucci, R. M. (2018). Morphological and petrographic analysis of ne wly identified stroma tolitic occurrences in the Lagoa do Jacaré Formation, Ba mbuí Group, Sta te of Minas Gerais, Brazil. Revista Brasileira de Paleontologia, 21, 3.

59. Galvão, P., Halihan, T., \& Hirata, R. (2016). The karst permeability scale effect of Se te Lagoas, MG, Brazil. Journal of Hydrology, 532, 149-162.

60. Bazarkina, E. F., Chou, I. M., Goncharov, A. F., \& Akinfiev, N. N. (2020). The Behavior of H2 in Aqueous Fluids under High Temperature and Pressure. Elements: An International Magazine of Mineralogy, Geochemistry, and Petrology, 16(1), 33-38

61. Charlou, J. L., Donval, J. P., Konn, C., Ondré As, H., Fouquet, Y., Jean-Ba ptiste, P., \& Fourré, E. (2010). High production and fluxes of $\mathrm{H} 2$ and $\mathrm{CH} 4$ and evidence of abiotic hydrocarbon synthesis by serpentinization in ultrama fic-hosted hydrothermal systems on the Mid-Atlantic Ridge. GMS, 188, 265-296.

62. Keir, R. S. (2010). A note on the fluxes of abiogenic methane and hydrogen from mid-ocean ridges. Geophysical re search letters, 37(24).

63. Cannat, M., Fontaine, F., \& Escartin, J. (2010). Serpentiniza tion and a ssociated hydrogen and methane fluxes at slow sprea ding ridges, in "Diversity Of Hydrothermal Systems On SlowSpreading Ocean Ridges", AGU Geophysical Monograph Series, V. 188. Eds: P.A. Rona, C. W. Devey, J. Dyment., B. J. Murton

64. Myagkiy, A., Brunet, F., Popov, C., Krüger, R., Guima rães, H., Sousa, R. S., Charlet, L., \& More tti, I. (2020). $\mathrm{H} 2$ dynamics in the soil of a H2-emitting zone (São Francisco Basin, Brazil): Microbial uptake quantification and reactive transport modelling. Applied Geochemistry, 112, 104474. 